Article

\title{
The Effects of Production System and Sex on the Sensory Quality Characteristics of Dorper Lamb
}

\author{
Louwrens Christiaan Hoffman 1,2,*(i), Bianca Claasen ${ }^{1}$, Daniël André Van der Merwe ${ }^{1}$, \\ Schalk Willem Petrus Cloete ${ }^{1,3}$ and Jasper Johannes Erasmus Cloete ${ }^{1,4}$
}

1 Department of Animal Sciences, Faculty of Agriculture and Forestry Sciences, University of Stellenbosch, Private Bag X1, Matieland 7602, South Africa; uaeclaasen@hotmail.com (B.C.); dvdmpok@gmail.com (D.A.V.d.M.); schalkc2@sun.ac.za (S.W.P.C.); jasperc@elsenburg.com (J.J.E.C.)

2 Centre for Nutrition and Food Sciences, Queensland Alliance for Agriculture and Food Innovation, University of Queensland, Coopers Plains, QLD 4108, Australia

3 Western Cape Department of Agriculture: Directorate Animal Sciences: Elsenburg, Private Bag X1, Elsenburg 7607, South Africa

4 Western Cape Department of Agriculture: Elsenburg Agricultural Training Institute, Private Bag X1, Elsenburg 7607, South Africa

* Correspondence: louwrens.hoffman@uq.edu.au

Received: 4 May 2020; Accepted: 29 May 2020; Published: 2 June 2020

check for updates

\begin{abstract}
The effect of production systems on the sensory quality characteristics of Dorper lambs was investigated. Sixty lambs (ewes, rams, castrates) were allocated into two production groups (feedlot or free-range) at weaning with equal numbers of each sex represented in each group. The lambs were fed for five (slaughter group 1) or six (slaughter group 2) weeks. Feedlot lambs were fed a commercial pelleted diet while free-range lambs utilized natural shrub pastures. Samples of the Longissimus thoracis muscle were used for sensory evaluation. Feedlot lambs produced meat that was juicier and more tender than meat from free-range lambs. Initial juiciness was also higher in the meat from the feedlot lambs. No aroma or flavour differences were observed. The meat from the free-range ram lambs (slaughter group 1) was the least tender, whereas the lamb flavour was also compromised in the free-range ram lambs. Free-range meat may not necessarily be distinguished from feedlot meat as far as aroma and flavour are concerned.
\end{abstract}

Keywords: feedlot; free-range; sensory meat quality; lamb

\section{Introduction}

Gastronomic satisfaction from the consumption of meat is mainly derived from tenderness, juiciness and flavour. Consumers consider meat tenderness the most important palatability trait [1], with some consumers expressing a willingness to pay a higher price for meat that could be certified as tender [2]. Juicy meat is also generally preferred [3]. Meat flavour contributes to overall product acceptability. These quality attributes need to be considered when raising animals to satisfy the consumer market.

A growing number of consumers have vocalised their preference for animal products of free-range origin [4]. Free-range products are perceived as natural, healthier and of higher quality than products from more intensive animal production systems [5,6]. Scientific investigations report differences between lamb carcasses from feedlot and free-range systems [7-9]. High planes of nutrition, often associated with feedlot diets, result in lambs that are generally fatter at slaughter compared to lambs on free-range diets. The fatter carcasses produced on feedlot diets show an improvement in meat tenderness through an increase in the intramuscular fat content relative to the muscle collagen [10]. 
Moreover, higher juiciness scores are associated with meat from lambs fed feedlot diets [11-14]. Fatter carcasses are also better insulated than lean carcasses, thus slowing down post-mortem chilling and improving meat tenderness by decreasing the extent of cold-induced muscle shortening. This also prolongs post-mortem proteolysis [15]. Animals that grow rapidly prior to slaughter, as is commonly found when high-quality feedlot diets are fed, produce tender meat [16]. The tenderness of meat is attributed to an increased protein turnover that results in higher concentrations of proteolytic enzymes in carcass tissues [17]. In addition, muscles from these faster growing animals tend to have less cross linked collagen [18]. In contrast, lambs fed low energy diets have also been reported to produce more tender meat than lambs fed a higher energy diet [19].

Some studies have shown that lamb sex has an effect on carcass composition, juiciness, tenderness and flavour [11,18]. In particular, intact male lambs produce leaner carcasses than castrates and ewes. Leaner carcasses are associated with less juicy and less tender meat compared to the fatter carcasses of ewes and castrate lambs [20,21]. Investigations on cattle did not detect significant differences in meat tenderness between bulls and steers. At the same age, meat from males is less tender than meat from females and this phenomenon is attributed to the higher calpastatin and $\mu$-calpain activity at $24 \mathrm{~h}$ post mortem in meat from males [22]. According to Pommier et al. [23] testosterone levels in males increase after puberty, causing an increase in the quantity of collagen in the muscle, which reduces the tenderness of meat.

Flavour volatiles may be affected by the feeding system or the feed given $[9,24,25]$. Feedlot diets alter fat composition and reduce flavour intensity while free-range diets produce lamb with a more intense flavour [26]. However, Muir et al. [15] observed no flavour differences when free-range and feedlot lambs were slaughtered at the same weight and/or fat cover. In addition, high-quality pastures may also result in no flavour differences between free-range and feedlot meat [25]. Sheep meat odour and flavour are also affected by sex and its interactions with the feeding system [11,26,27].

Literature which compares the effect of the production/feeding system on the sensory meat characteristics of all three sex groups under southern African conditions is scarce. Most literature compares either the feeding system on the sensory meat quality characteristics between ewes and rams or rams and castrates. The Dorper sheep breed is the second most abundant sheep breed in South Africa and has been selected for its hardiness and adaptability under harsh conditions [28,29]. While lamb from Dorper sheep from different extensive grazing systems has been evaluated [24], the comparison of a free-range finishing regime with feedlot finishing for Dorper sheep under South African conditions has not yet been reported. In this study, Dorper lambs of all sex groups of the same age were finished off either in feedlot or in free-range conditions and slaughtered after a predetermined period. The main objectives of this study were to investigate the effect of the production system (free-range vs. feedlot) on the sensory characteristics of Dorper lamb, while the effect of sex on lamb sensory characteristics was studied as a secondary objective.

\section{Materials and Methods}

\subsection{Experimental Outlay}

Sixty Dorper lambs at the Nortier research farm (Coordinates: 32.035147078S, 18.331839395E) of the Western Cape Department of Agriculture were randomly sorted into two production groups, namely feedlot and free-range, subsequent to weaning. Each of the production groups consisted of 10 lambs from each sex class (ewes, rams and castrates). The lambs were allocated to these treatments at weaning (121 \pm 5 days of age) at an average weight of $36.3 \pm 3.2 \mathrm{~kg}$. The feedlot lambs were fed a commercial pelleted diet while the free-range group grazed natural shrub pastures until slaughter. In the feedlot production groups, the lambs of different sexes were reared separately in three pens $(10 \mathrm{~m} \times 6 \mathrm{~m})$, with $6 \mathrm{~m}^{2}$ space per lamb allowed. The different sexes of the free-range production group were in three adjacent and extensive grazing paddocks, with an area of 15 ha each, so as to ensure the lambs had access to similar grazing vegetation. Owing to logistic considerations, one group was 
slaughtered 5 weeks into the study while the others were slaughtered a week later. At each slaughter occasion, 15 lambs from both production groups were randomly selected (representing five lambs from each sex class). The experimental outlay (selection of the lambs, description of the production system, diet composition, plants grazed and selection of slaughter lambs) is detailed in the paper by Cloete et al. [30]. The samples from the lambs slaughtered at week 5 and week 6 were both included for the sensory analysis. The average live weights of the lambs at slaughter was $43.2 \mathrm{~kg}$. This did not differ between the production groups. The slaughter weights of the rams $(46.4 \mathrm{~kg})$ and castrates $(44.4 \mathrm{~kg})$ on the other hand were heavier than those of the ewe lambs $(38.7 \mathrm{~kg})$.

Following slaughter, the carcasses were refrigerated for $48 \mathrm{~h}$ at $4{ }^{\circ} \mathrm{C}$. The Longissimus thoracis (LT) muscles were then excised between the 8th to 11th ribs from both sides of each carcass. Excised LT muscles were placed in individually coded bags and transported in an insulated cool box to the Meat Science laboratory at Stellenbosch University (Stellenbosch, South Africa) for further analyses. The LT muscles from the right side of each carcass were used for subcutaneous fat thickness measurements [30]. The LT muscle samples from the left side of the carcass (with the subcutaneous fat layer still intact) were vacuum sealed and stored at $-18{ }^{\circ} \mathrm{C}$ until required for sensory meat quality evaluation.

\subsection{Preparation of Samples}

Twenty-four hours before every sensory evaluation session, six LT muscles (one from each sex of each treatment) were removed from the freezer and defrosted in a refrigerator at $2-4{ }^{\circ} \mathrm{C}$. After $24 \mathrm{~h}$, each sample was removed from its packaging and placed on a metal rack (covered with foil paper with the reflective side up) in a coded oven bag $\left(G{ }^{\circledR}\right)$. A thermocouple probe, connected to a handheld digital temperature monitor (Hanna Instruments, Johannesburg, South Africa) was inserted into the centre of each sample and the samples were roasted to an internal temperature of $68^{\circ} \mathrm{C}$ in an oven preheated at $160^{\circ} \mathrm{C}$. The meat was roasted in two Defy ovens connected to a computerized electronic temperature system. At a core temperature of $68^{\circ} \mathrm{C}$, the meat samples were removed from the oven and allowed to cool for five minutes. All the visible fat and meat surfaces exposed to the cooking environment were trimmed. Each sample was cut into $1 \mathrm{~cm}^{3}$ cubes, perpendicular to the fibre direction. Thereafter, the cubes were individually wrapped in aluminium foil and reheated at $100{ }^{\circ} \mathrm{C}$ for $10 \mathrm{~min}$ before the commencement of each sensory evaluation session.

\subsection{Sensory Analysis}

The sensory panel consisted of seven trained assessors, between the ages of 40 and 60 years, previously selected for their flavour and texture sensitivity according to the guidelines of the American Meat Science Association (Nebraska, USA) [31]. The members of this sensory panel routinely volunteered to take part in sensory analyses; tipically more than half the panellists selected would have prior experience in analysing meat products. The panel was further trained using the consensus method described by Lawless and Heymann [32]. Attributes were rated on the basis of $100 \mathrm{~mm}$ unstructured lines with anchor points at each end, zero (left anchor point) representing the minimum and one hundred (right anchor point) representing the maximum. Scores were considered as the distance from the left anchor point. For all the sensory attributes analysed, except for flavour, a higher value depicted a better score. One sample from each sex group in each production system was used to train the panel for sensory attributes. The judges agreed on a consensus list of attributes for describing lamb which included the intensity of the lamb aroma, the impression of initial juiciness, the sustained juiciness, the impression of tenderness and the overall lamb flavour. Verbal definitions of the sensory attributes evaluated for the lamb are given in Table 1. 
Table 1. Verbal definitions used to describe the sensory attributes of the Dorper lamb.

\begin{tabular}{ccc}
\hline Attribute & Definition & Scale \\
\hline \multirow{2}{*}{ Lamb aroma } & Aroma associated with lamb & $0=$ No lamb aroma \\
& The amount of fluid that exudates on the cut surface & $100=$ strong lamb aroma \\
Initial juiciness & $0=$ extremely dry \\
& when pressed between thumb and fore finger & $100=$ extremely juicy \\
Sustained juiciness & The degree of juiciness perceived after the first two to & $0=$ extremely dry \\
& three chews between the molar teeth & $100=$ extremely juicy \\
Tenderness & Impression of tenderness after the first two to three & $0=$ extremely tender \\
& chews between the molar teeth & $100=$ extremely tough \\
Flavour & Flavour associated with lamb as a combination of & $0=$ bland flavour \\
& taste and swallowing & $100=$ intense flavour \\
\hline
\end{tabular}

\subsection{Sensory Procedure}

The samples were served and evaluated during ten sessions. The panellists were seated in individual sensory booths in a controlled temperature room (natural day light at $22^{\circ} \mathrm{C}$ ). The meat samples (individually wrapped in aluminium foil) were placed in coded glass ramekins, preheated at $100{ }^{\circ} \mathrm{C}$ and presented in a completely randomized order as pertaining to production system and sex. The meat was evaluated using the standard questionnaire of the American Meat Science Association [31]. The aroma of the samples was assessed immediately after un-wrapping the aluminium foil. The initial juiciness was assessed by pressing the sample between the forefinger and the thumb. The sustained juiciness, tenderness and the flavour attributes were assessed by tasting the sample. For each session, the panel members were offered six different meat samples and the attributes were individually recorded. Wafer biscuits, apple slices and distilled water were used by the assessors to cleanse their palates between samples. The panellists were allowed $20 \mathrm{~min}$ for each testing session, with extra time being allowed if panellists needed more time to complete the testing.

\subsection{Statistical Analysis of Data}

The sensory data was subject to an analysis of variance (ANOVA) using the PROC GLM of the SAS version 9.1.3 statistical software [33] to evaluate the different sources of variation in the sensory attributes: lamb aroma, initial juiciness, sustained juiciness, tenderness and overall flavour. Production system, sex and slaughter date were the main effects and all the interactions between the main effects were considered. The Shapiro-Wilk test was performed to test for normality [34]. The sensory experiment consisted of three treatment combinations, each replicated ten times by seven panel members in a completely randomized design. The treatment combinations involved a $2 \times 3 \times 2$ factorial design, arising from the combination of two production systems (feedlot and free-range) and three sex groups (ewes, castrates and ram lambs) and two slaughter dates (slaughter group 1 and 2). A $p$-value smaller than $5 \%(p<0.05)$ was considered significant. Where applicable, Pearson's correlations were calculated between the various sensory attributes and the physical and chemical characteristics reported in the paper by Cloete et al. [30].

\section{Results}

The analysis of variance (ANOVA) of the lamb attributes-lamb aroma, initial meat juiciness, sustained meat juiciness, tenderness and flavour-are presented in Table 2. None of the main effects of the production system, sex or slaughter group the affected lamb aroma. However, the two-way interaction between the production system and sex was significant for the lamb flavour. Slaughter date had no effect on any of the sensory attributes except tenderness where a three-way interaction between the production system, sex and the slaughter date, was significant. 
Table 2. Analysis of variance (ANOVA) for the attributes: aroma; initial juiciness; sustained juiciness; tenderness; and flavour for Dorper lambs (rams, ewes, castrates) reared either under free-range conditions or in a feedlot system.

\begin{tabular}{|c|c|c|c|c|c|c|c|c|c|c|c|}
\hline \multirow[t]{2}{*}{ Source } & \multirow[t]{2}{*}{$\mathrm{dF}$} & \multicolumn{2}{|c|}{ Lamb aroma } & \multicolumn{2}{|c|}{$\begin{array}{c}\text { Initial } \\
\text { Juiciness }\end{array}$} & \multicolumn{2}{|c|}{$\begin{array}{l}\text { Sustained } \\
\text { Juiciness }\end{array}$} & \multicolumn{2}{|c|}{ Tenderness } & \multicolumn{2}{|c|}{ Flavour } \\
\hline & & MS & $p$-value & MS & $p$-value & MS & $p$-value & MS & $p$-value & MS & $p$-value \\
\hline Production system & 1 & 32.89 & 0.350 & 289.63 & 0.064 & 486.27 & 0.015 & 549.38 & 0.024 & 2.67 & 0.599 \\
\hline Sex & 2 & 48.35 & 0.280 & 22.40 & 0.756 & 122.15 & 0.211 & 640.02 & 0.004 & 35.77 & 0.031 \\
\hline Slaughter date & 1 & 74.41 & 0.160 & 96.03 & 0.278 & 169.69 & 0.141 & 145.80 & 0.234 & 0.02 & 0.965 \\
\hline Production system $\times$ Sex & 2 & 16.99 & 0.640 & 175.81 & 0.123 & 18.95 & 0.779 & 137.59 & 0.264 & 46.09 & 0.013 \\
\hline $\begin{array}{c}\text { Production system } \times \\
\text { Slaughter date }\end{array}$ & 1 & 0.01 & 0.990 & 0.04 & 0.982 & 0.49 & 0.936 & 3.67 & 0.850 & 0.74 & 0.780 \\
\hline Sex $\times$ slaughter date & 2 & 36.50 & 0.380 & 30.96 & 0.680 & 7.64 & 0.900 & 10.53 & 0.900 & 7.77 & 0.450 \\
\hline $\begin{array}{c}\text { Production system } \times \operatorname{Sex} \times \\
\text { Slaughter date }\end{array}$ & 2 & 35.50 & 0.390 & 53.81 & 0.514 & 7.73 & 0.903 & 347.62 & 0.040 & 15.37 & 0.210 \\
\hline
\end{tabular}

MS denotes the mean squares of the attributes; $\mathrm{dF}=$ degrees of freedom.

Meat from the lambs slaughtered on the two slaughter dates did not differ with respect to any of the sensory traits evaluated in Table $3(p>0.05)$. Meat from the feedlot lambs tended $(p=0.064)$ to have a higher initial juiciness (Table 3 ). Significantly higher sustained juiciness scores were also observed for meat from feedlot lambs compared to the meat from the free-range lambs $(p=0.015)$. A positive correlation was observed between the initial juiciness and the sustained juiciness $(p<0.05$; $r=0.800$ ) while a negative correlation was present between the initial juiciness and the drip loss $(p<0.05 ; r=-0.54)$ as well as between the initial juiciness and the cooking loss $(p<0.05 ; r=-0.418)$. The traits reported in Table 3 were unaffected by sex $(p>0.05)$.

Table 3. Means ( \pm s.d.) depicting the effect of the slaughter date, production system and the sex on the sensory attributes of the Dorper lamb.

\begin{tabular}{|c|c|c|c|c|c|c|c|}
\hline \multirow{2}{*}{ Attribute } & \multicolumn{2}{|c|}{ Slaughter Date } & \multicolumn{2}{|c|}{ Production System } & \multicolumn{3}{|c|}{ Sex } \\
\hline & 1 & 2 & Feedlot & Free Range & Castrates & Ewes & Rams \\
\hline Aroma & $81.83^{\mathrm{a}} \pm 8.91$ & $83.14^{a} \pm 7.92$ & $82.82^{\mathrm{a}} \pm 8.52$ & $82.15^{\mathrm{a}} \pm 8.37$ & $82.17^{a} \pm 8.07$ & $83.02^{a} \pm 8.76$ & $82.26^{\mathrm{a}} \pm 8.52$ \\
\hline Initial juiciness & $81.72^{\mathrm{a}} \pm 8.16$ & $84.25^{a} \pm 7.08$ & $83.94^{\mathrm{y}} \pm 7.58$ & $82.02^{\mathrm{z}} \pm 7.80$ & $83.25^{\mathrm{a}} \pm 7.42$ & $83.70^{a} \pm 7.95$ & $82.33^{a} \pm 7.86$ \\
\hline Sustained juiciness & $79.38^{a} \pm 9.31$ & $81.63^{a} \pm 8.69$ & $81.67^{\mathrm{a}} \pm 8.82$ & $79.33^{b} \pm 9.18$ & $80.75^{a} \pm 8.36$ & $81.38^{a} \pm 9.88$ & $79.40^{\mathrm{a}} \pm 8.84$ \\
\hline
\end{tabular}

The three-way interaction between the production system, sex and the slaughter date, was significant $(p<0.05)$ for tenderness (Table 4$)$. The meat from ewe lambs tended to be more tender than the meat from castrates although the difference was not significant. The meat from free-range ram lambs slaughtered on slaughter date 1 (denoted as FR-ram-1) had the lowest tenderness scores.

Table 4. Means ( \pm s.d.) depicting the effect of the three-way interactions (production system $\times \operatorname{sex} \times$ slaughter date) on the tenderness scores of Dorper lambs.

\begin{tabular}{cc}
\hline Production System $\times$ Sex $\times$ Slaughter Date & Tenderness \\
\hline FL-castrate-1 & $87.87 \pm 8.02$ \\
FL-castrate-2 & $85.57 \pm 9.00$ \\
FL-ewe-1 & $89.04 \pm 6.62$ \\
FL-ewe-2 & $87.67 \pm 9.47$ \\
FL-ram-1 & $84.83 \pm 8.90$ \\
FL-ram-2 & $85.33 \pm 6.31$ \\
FR-castrate-1 & $85.31 \pm 8.66$ \\
FR-castrate-2 & $87.48 \pm 8.08$ \\
FR-ewe-1 & $86.50 \pm 7.75$ \\
FR-ewe-2 & $84.87 \pm 10.03$ \\
FR-ram-1 & $79.38 \pm 8.24$ \\
FR-ram-2 & $81.73 \pm 8.43$ \\
\hline
\end{tabular}

Where FL and FR refer to the production systems, feedlot and free range, respectively. The sexes are denoted by castrate, ewe and ram, while the slaughter date is denoted as either 1 or 2 . 
A two-way interaction $(p<0.05)$ between the feeding system and the sex (Table 5) was observed for flavour. Free-range ram lambs scored the lowest for flavour while the free-range ewe lambs scored the highest. It was, however, noted that all the groups scored above 80 on a $100 \mathrm{~mm}$ scale.

Table 5. Means ( \pm s.d.) depicting the effect of the two-way interaction (production system $\times$ sex) on the flavour score of Dorper lambs.

\begin{tabular}{cc}
\hline Production System $\times$ Sex & Flavour \\
\hline FL-castrate & $82.37^{\mathrm{a}} \pm 7.92$ \\
FL-ewe & $82.64^{\mathrm{a}} \pm 8.77$ \\
FL-ram & $82.71^{\mathrm{a}} \pm 8.81$ \\
FR-castrate & $82.95^{\mathrm{a}} \pm 7.56$ \\
FR-ewe & $82.98^{\mathrm{a}} \pm 8.32$ \\
FR-ram & $80.98^{\mathrm{b}} \pm 7.39$ \\
\hline
\end{tabular}

a,b Different subscripts differ at $p<0.05$. FL and FR refer to the production systems, feedlot or free range.

\section{Discussion}

It is well known that initial meat juiciness is related to the water holding capacity (WHC) of meat. Higher WHC values indicate higher initial juiciness scores whereas lower WHC values indicate lower initial juiciness scores. This is reflected by the negative correlation found in this study between the initial meat juiciness and drip loss, $(p<0.002 ; r=-0.54)$, where higher levels of drip loss are indicative of a low WHC of meat. Sustained meat juiciness depends on the amount of liquid released during mastication, both from the food and saliva. The higher intramuscular lipid content of the meat from feedlot lambs (in absolute terms) compared to that of free-range lambs ( $3.64 \% \mathrm{vs} .3 .43 \%$, respectively) [30] might have affected the perception of meat juiciness $(p<0.05 ; r=0.43)$ by stimulating saliva flow.

The less tender meat of free-range lambs may be attributed to the higher level of exercise of these lambs during grazing activity [35]. This result is in agreement with that of Vestergaard et al. [36] who also suggested physical activity as the reason for the lower tenderness scores observed in bulls raised on pastures compared to the tie-stalled bulls that were fed a concentrate-based diet. Lowe et al. [37] did not find any significant differences in tenderness between free-range and feedlot lambs, based on mechanical shear force values, possibly because nutrition was adequate and stress levels were low in their experiment.

It is known that at the same age, meat from male lambs is less tender than that from female lambs (Table 4) [22,38]. This is the result of an increase in the excretion of testosterone in males after puberty, leading to an increase in the amount of collagen in muscles, which in turn, results in reduced tenderness $[23,39]$. Other research results indicate that meat from male animals have a higher calpastatin activity $24 \mathrm{hr}$ post-mortem which may decrease the quantity of myofibrillar protein proteolysis thus resulting in less tender meat [22]. Furthermore, Pommier et al. [23] also attributed less tender meat from males at the same age, compared to ewes or castrates, to testicular hormones. Studies involving beef cattle also showed that meat from bull carcasses was less tender and hence less palatable than meat from steer carcasses $[20,21,40,41]$. However, some investigations have been unable to detect significant differences between the meat from bulls and steers [42]. As mentioned earlier, intact males generally produce leaner carcasses (than ewes and castrates) that are associated with less tender meat $[20,21,40]$. In addition, low energy diets such as free-range diets are often associated with less tender meat although contradictory results have been reported [19,43]. Rousset-Akrim et al. [26] accordingly showed that lambs raised under free-range conditions had a more intense flavour than lambs raised under feedlot conditions although their difference applied across sex groups. 


\section{Conclusions}

The results from this investigation indicated that the production system affects some sensory characteristics of Dorper lambs. The advantage of feedlot-feeding appears to be its ability to produce juicier meat compared to free-range-feeding-a phenomenon attributed to the higher lipid content of the former. Meat tenderness was compromised in ram lambs in the free-range production system for lambs slaughtered in slaughter group 1 when the production system by sex by slaughter date interaction was considered, an observation which is difficult to explain. Overall, the production system had no effect on the aroma of Dorper lamb. However, lamb flavour was more intense in ram lambs from the free-range production system when the feeding system by sex interaction was considered. Meat tenderness was evidently compromised in ram lambs compared to the other sex groups. As the organoleptic differences between the two production systems were minimal, other social cues such as carbon footprint, perceived animal welfare, etc. may play a role in influencing the consumer selection of the production system's lamb that they would consume-this warrants further research.

Author Contributions: B.C. was responsible for the collection of data, interpretation of results and writing the initial draft of this manuscript. L.C.H., S.W.P.C. and J.J.E.C. conceptualised the hypothesis, the design of the experiment as well as contributed in the interpretation of results and critical review of the manuscript. S.W.P.C. also assisted in the statistical analysis of the data. D.A.V.d.M. was responsible for revising the manuscript and preparing it for submission. All authors have read and approved the manuscript.

Funding: This research was funded by the Western Cape Agricultural Research Trust (grant number 0300/01). This research was also supported by the South African Research Chairs Initiative (SARChI) and partly funded by the South African Department of Science and Technology (UID number: 84633), as administered by the National Research Foundation (NRF) of South Africa, and partly Stellenbosch University. Any opinions, findings and conclusions or recommendations expressed in this material are that of the author(s) and the National Research Foundation does not accept any liability in this regard.

Acknowledgments: The technical assistance of the staff at the Nortier research farm is appreciated, as is the financial contribution of the Western Cape Agricultural Research Trust. This work is based on the research supported by the South African Research Chairs Initiative of the Department of Science and Technology and the National Research Foundation of South Africa (Grant No. UID 84633). Any opinion, finding and conclusion or recommendation expressed in this material is that of the author(s), and the National Research Foundation does not accept any liability in this regard.

Conflicts of Interest: The authors declare that there are no conflict of interest regarding this study.

\section{References}

1. Pietrasik, Z.; Shand, P.J. Effect of blade tenderized and tumbling time on the processing characteristics and tenderness of injected cooked roast beef. Meat Sci. 2004, 66, 871-879. [CrossRef] [PubMed]

2. Miller, M.F.; Carr, M.A.; Ramsey, C.B.; Crockett, K.L.; Hoover, L.C. Consumer thresholds for establishing the value of beef tenderness. J. Anim. Sci. 2001, 79, 3062-3068. [CrossRef] [PubMed]

3. Risvik, E. Sensory properties and preferences. Meat Sci. 1994, 36, 67-77. [CrossRef]

4. Verberke, W.A.J.; Viaene, J. Ethical challenges for livestock Production: Meeting consumer concern about meat safety and animal welfare. J. Agric. Environ. Ethics 2000, 12, 141-151. [CrossRef]

5. McEachern, M.G.; Willock, J. Producers and consumers of organic meat: A focus on attitudes and motivations. Br. Food J. 2004, 106, 534-552. [CrossRef]

6. Davies, A.; Titterington, A.J.; Cochrane, C. Who buys organic food? A profile of the purchasers of organic food in Northern Ireland. Br. Food J. 1995, 97, 17-23. [CrossRef]

7. Díaz, M.T.; Velasco, S.; Caneque, V.; Lauzurica, S.; de Huidobro, F.R.; Perez, C.; Gonzalez, J.; Manzanares, C. The use of concentrate or pasture for fattening lambs and its effect on carcass and meat quality. Small Rumin. Res. 2002, 43, 257-268. [CrossRef]

8. Murphy, T.A.; Loerch, S.C.; McClure, K.E.; Solomon, M.B. Effects of restricted feeding on growth performance and carcass composition of lambs subjected to different nutritional treatments. J. Anim. Sci. 1994, 72, 3131-3137. [CrossRef]

9. Crouse, J.D.; Busboom, J.R.; Field, R.A.; Ferrell, C.L. The effects of breed, diet, sex, location and slaughter weight on lamb growth, carcass composition and meat flavour. J. Anim. Sci. 1981, 53, 376-381. [CrossRef] 
10. Crouse, J.D.; Field, R.A. Effect of dietary energy intake on carcass composition and palatability of different weight carcasses from ewe and ram lambs. J. Anim. Sci. 1978, 47, 1207-1218. [CrossRef]

11. Priolo, A.; Micol, D.; Agabrie, J.; Prache, S.; Dransfield, E. The effect of grass or concentrate feeding system on lamb carcass and meat quality. Meat Sci. 2002, 62, 179-185. [CrossRef]

12. Arnold, A.M.; Meyer, H.H. Effects of gender, time of castration, genotype and feeding regime on lamb growth and carcass fatness. J. Anim. Sci. 1988, 66, 2468-2475. [CrossRef] [PubMed]

13. Notter, D.R.; Kelly, R.F.; McClaugherty, F.S. Effects of ewe breed and management system on efficiency of lamb growth production: II. Lamb growth, survival and carcass characteristics. J. Anim. Sci. 1991, 69, $22-33$. [CrossRef] [PubMed]

14. Oltjen, R.R.; Ramsey, T.S.; Putman, P.A. All forage diets for finishing beef steers. J. Anim. Sci. 1971, 46, 716-724.

15. Muir, P.D.; Beaker, J.M.; Bown, M.D. Effects of forage and grain feeding systems on beef quality. J. Agric. Res. 1998, 41, 623-635.

16. Koohmaraie, M.; Kent, M.P.; Schackelford, S.D.; Veiseth, E.; Wheeler, T.L. Meat tenderness and muscle growth: Is there any relationship? Meat Sci. 2002, 62, 345-352. [CrossRef]

17. Fishell, V.K.; Aberle, E.D.; Judge, M.D.; Perry, T.W. Palatability and muscle properties of beef as influenced by pre-slaughter growth rate. J. Anim. Sci. 1985, 61, 151-157. [CrossRef]

18. Lawrie, R.A. Meat Science, 6th ed.; Pergamon Press: New York, NY, USA, 1998.

19. Resconi, V.C.; Campo, M.M.; i Furnols, M.F.; Montossi, F.; Sanudo, C. Sensory evaluation of castrated lambs finished on different proportions of pasture and concentrate feeding systems. Meat Sci. 2009, 83, 31-37. [CrossRef]

20. Seideman, S.C.; Cross, H.R.; Oltjen, R.R.; Scanbacher, B.D. Utilization of intact male red meat production. J. Anim. Sci. 1982, 55, 826-840. [CrossRef]

21. Gkarane, V.; Allen, P.; Gravador, R.S.; Diskin, M.G.; Claffey, N.A.; Fahey, A.G.; Brunton, N.P.; Farmer, L.J.; Moloney, A.P.; Monahan, F.J. Effect of castration and age at slaughter on sensory perception of lamb meat. Small Rumin. Res. 2017, 157, 65-74. [CrossRef]

22. Morgan, J.B.; Wheeler, M.; Koohmaraie, M.; Savell, J.W.; Crouse, J.D. Meat tenderness and calpain proteolytic system in longissimus muscle of young bulls and steers. J. Anim. Sci. 1993, 71, 1471-1476. [CrossRef] [PubMed]

23. Pommier, S.A.; Fahmy, M.H.; Poste, L.M.; Butler, G. Effects of sex, electrical stimulation and conditioning time on carcass and meat characteristics of Roman lambs. Food Qual. Prefer. 1989, 1, 127-132. [CrossRef]

24. Erasmus, S.W.; Hoffman, L.C.; Muller, M.; van der Rijst, M. Variation in the sensory profile of South African Dorper lamb from extensive grazing systems. Small Rumin. Res. 2016, 144, 62-74. [CrossRef]

25. Melton, S.L. Effect of feeds on flavour of red meat, a review. J. Anim. Sci. 1990, 68, 4421-4435. [CrossRef]

26. Rousset-Akrim, S.; Young, O.A.; Berdague, J.L. Diet and growth effects in panel assessment of sheep meat odour and flavour. Meat Sci. 1997, 45, 169-181. [CrossRef]

27. French, P.; O’Riordan, E.G.; Monahan, F.J.; Caffrey, P.J.; Mooney, M.T.; Troy, D.J.; Moloney, A.P. The eating quality of steers fed grass and/or concentrates. Meat Sci. 2001, 57, 379-386. [CrossRef]

28. Milne, C. The history of Dorper sheep. Small Rumin. Res. 2000, 36, 99-102. [CrossRef]

29. Schoeman, S.J. A comparative assessment of Dorper sheep in different production environments and systems. Small Rumin. Res. 2000, 36, 137-146. [CrossRef]

30. Cloete, J.J.E.; Hoffman, L.C.; Claasen, B.; Cloete, S.W.P. Effect of production system on the growth rate, carcass characteristics and carcass composition of Dorper lambs. Livest. Res. Rural Dev. 2012, 24, 101.

31. AMSA. Research Guidelines for Cookery, Sensory Evaluation and Instrumental Tenderness Measurements of Fresh Meat; National Livestock and Meat Board: Chicago, IL, USA, 1995; pp. 1-33.

32. Lawless, H.T.; Heymann, H. Sensory Evaluation of Food: Principles and Practices; Aspen Publishers: Gaithersburg, MD, USA, 1998.

33. SAS Institute. SAS/Stat User's Guide Version 9, 1st ed.; SAS Institute Inc., SAS Campus Drive: Cary, NC, USA, 2006; Volume 3, p. 27513.

34. Shapiro, S.S.; Wilk, M.B. An analysis of variance test for normality (complete samples). Biometrika 1965, 52, 591-611. [CrossRef]

35. Ekiz, B.; Yilmaz, A.; Ozcan, M.; Kocak, O. Effect of production system on carcass measurements and meat quality of Kivircik lambs. Meat Sci. 2012, 90, 465-471. [CrossRef] [PubMed] 
36. Vestergaard, M.; Therkilsen, M.; Henckel, P.; Jensen, L.R.; Anderson, H.R.; Sejrsen, K. Influence of feeding intensity, grazing and finishing feeding on meat and eating quality of young bulls and the relationship between muscles fibre characteristics, fibre fragmentation and meat tenderness. Meat Sci. 2000, 54, 187-195. [CrossRef]

37. Lowe, T.E.; Peachy, B.M.; Devine, C.E. The effect of nutritional supplements on growth rate, stress responsiveness, muscle glycogen and meat tenderness in pastoral lambs. Meat Sci. 2002, 62, 391-397. [CrossRef]

38. Johnson, P.L.; Purchas, R.W.; McEwan, J.C.; Blair, H.T. Carcass composition and meat quality differences between pasture-reared ewe and ram lambs. Meat Sci. 2005, 71, 383-391. [CrossRef]

39. Young, O.A.; Lane, G.A.; Podmore, C.; Fraser, K.; Agnew, M.J.; Cummings, T.L.; Cox, N.R. Changes in composition and quality characteristics of ovine meat and fat from castrates and rams aged to 2 years. N. Z. J. Agric. Res. 2006, 49, 419-430. [CrossRef]

40. Peachey, B.M.; Purchas, R.W.; Duizer, L.M. Relationships between sensory and objective measures of meat tenderness of beef $\mathrm{m}$. longissimus thoracis from bulls and steers. Meat Sci. 2002, 60, 211-218. [CrossRef]

41. Rodriguez, J.; Unruh, J.; Villarreal, M.; Murillo, O.; Rojas, S.; Camacho, J.; Jaeger, J.; Reinhardt, C. Carcass and meat quality characteristics of Brahman cross bulls and steers finished on tropical pastures in Costa Rica. Meat Sci. 2014, 96, 1340-1344. [CrossRef]

42. Vanderwert, W.; McKeith, F.K.; Bechter, P.J.; Berger, L.L. Influence of zeranol implants and electrical stimulation on the palatability traits of five muscles in Angus and Limousin bulls and steers. J. Anim. Sci. 1986, 63, 114-120. [CrossRef]

43. Pereira, S.; Costa, R.; Castro Filho, E.; Almeida, M.; Rodriques, J.; Bertoco, J.; Feliciano, A.; Barducci, R.; van Cleef, E.; Ezequiel, J. PSXV-39 Soybean molasses improves texture of meat from feedlot lambs. J. Anim. Sci. 2018, 96, 477. [CrossRef]

(C) 2020 by the authors. Licensee MDPI, Basel, Switzerland. This article is an open access article distributed under the terms and conditions of the Creative Commons Attribution (CC BY) license (http://creativecommons.org/licenses/by/4.0/). 